\title{
HAKIKAT KURIKULUM PENDIDIKAN ISLAM
}

\author{
Muhammad Roihan Alhaddad \\ Sekolah Tinggi Ilmu Tarbiyah Raudhatul Ulum Sakatiga \\ Email: roy_saka02@yahoo.co.id
}

\begin{abstract}
Abstrak
Pengertian kurikulum dalam pandangan modern merupakan program pendidikan yang disediakan oleh sekolah, yang tidak hanya sebatas bidang studi dan kegiatan belajarnya saja, akan tetapi meliputi segala sesuatu yang dapat mempengaruhi perkembangan dan pembentukan pribadi peserta didik sesuai dengan tujuan pendidikan yang diharapkan sehingga dapat meningkatkan mutu kehidupannya, yang pelaksanaannya bukan saja di sekolah tetapi juga di luar sekolah. Ada 4 komponen utama kurikulum, yaitu tujuan-tujuan yang ingin dicapai, pengetahuan (knowledge), metode dan cara-cara mengajar serta metode dan cara penilaian (evaluasi).Prinsip-prinsip kurikulum dalam Islam antara lain : prinsip berasaskan Islam, prinsip mengarah kepada tujuan, prinsip (integritas) antar mata pelajaran, prinsip relevansi, prinsip fleksibilitas, prinsip integritas, prinsip efisiensi, prinsip kontinuitas, prinsip individualitas, prinsip kesamaan, prinsip kedinamisan, prinsip keseimbangan dan prinsip efektifitas.
\end{abstract}

Kata Kunci: Kurikulum, Pendidikan, Islam

\section{Pendahuluan}

Kurikulum merupakan salah satu komponen yang sangat menentukan dalam suatu sistem pendidikan, karena itu kurikulum merupakan alat untuk mencapai tujuan pendidikan dan sekaligus sebagai pedoman dalam pelaksanaan pengajaran pada semua jenis dan tingkat pendidikan.

Tujuan pendidikan di suatu bangsa atau negara ditentukan oleh falsafah dan pandangan hidup bangsa atau negara tersebut. Berbedanya falsafah dan pandangan hidup suatu bangsa atau negara menyebabkan berbeda pula tujuan yang hendak dicapai dalam pendidikan tersebut dan sekaligus akan berpengaruh pula terhadap negara tersebut. Setiap pendidik harus memahami perkembangan kurikulum, karena merupakan suatu formulasi pedagogis yang paling penting dalam konteks pendidikan, dalam kurikulum akan tergambar bagaimana usaha yang dilakukan untuk membantu peserta didik dalam mengembangkan potensinya berupa fisik, intelektual, emosional, sosial dan keagamaan.

Dengan memahami kurikulum, para pendidik dapat memilih dan menentukan tujuan pembelajaran, metode, teknik, media pembelajaran dan alat evaluasi pengajaran yang sesuai dan tepat. Untuk itu dalam melakukan kajian terhadap keberhasilan sistem pendidikan ditentukan oleh tujuan yang realistis, dapat diterima oleh semua pihak, sarana dan organisasi yang baik, intensitas pekerjaan yang 


\section{Hakikat Kurikulum Pendidikan Islam Muhammad Roihan Alhaddad}

realistis tinggi dan kurikulum yang tepat guna. Oleh karena itu sudah sewajarnya para pendidik dan tenaga kependidikan bidang pendidikan Islam memahami kurikulum serta berusaha mengembangkannya. (Ramayulis, 2008:149)

\section{Pembahasan}

\section{Hakikat Kurikulum}

Secara etimologi, kurikulum berasal dari bahasa Yunani, yaitu curir yang artinya pelari dan curere yang berarti jarak yang ditempuh oleh pelari. Istilah ini pada mulanya digunakan dalam dunia olahraga yang berarti "a litle race course" yang artinya suatu jarak yang harus ditempuh dalam pertandingan olahraga. Berdasarkan pengertian ini, dalam konteks dengan dunia pendidikan, memberinya pengertian sebagai "circle of instruction" yaitu suatu lingkaran pengajaran di mana guru dan mood (suasana hati) terlibat di dalamnya. Sementara pendapat yang lain dikemukakan bahwa kurikulum adalah arena pertandingan, tempat pelajaran bertanding untuk menguasai pelajaran guna mencapai garis finis berupa ijazah, diploma atau gelar kesarjanaan. (Samsul Nizar, 2002:55-56)

Dalam bahasa Arab, kata kurikulum biasa diungkapkan dengan manhaj yang berarti jalan yang terang yang dilalui oleh manusia pada berbagai bidang kehidupan. Sedangkan kurikulum pendidikan (manhaj al-dirasah) dalam Kamus Tarbiyah adalah seperangkat perencanaan dan media yang dijadikan acuan oleh lembaga pendidikan dalam mewujudkan tujuan-tujuan pendidikan. (Hasan Langgulung, 1986:176)

Adapun secara terminologi, para ahli telah banyak mendefinisikan kurikulum diantaranya: (Ramayulis, 2008:150-151)

a. Ramayulis mengutip dari Crow dan Crow mendefinisikan bahwa kurikulum adalah rancangan pengajaran atau sejumlah mata pelajaran yang disusun secara sistematis untuk menyelesaikan suatu program untuk memperoleh ijazah.

b. Ramayulis mengutip dari M. Arifin memandang kurikulum sebagai seluruh bahan pelajaran yang harus disajikan dalam proses kependidikan dalam suatu sistem institusional pendidikan.

c. Ramayulis mengutip dari Zakiah Daradjat, memandang kurikulum sebagai suatu program yang direncanakan dalam bidang pendidikan dan dilaksanakan untuk mencapai sejumlah tujuan-tujuan pendidikan tertentu.

d. Ramayulis mengutip dari Dr. Addamardasyi Sarhan dan Dr. Munir Kamil memandang bahwa kurikulum adalah sejumlah pengalaman pendidikan, kebudayaan, sosial, olahraga dan kesenian yang disediakan oleh sekolah bagi peserta didiknya di dalam dan di luar sekolah dengan maksud menolong untuk berkembang menyeluruh dalam segala segi dan merubah tingkah laku mereka sesuai dengan tujuan-tujuan pendidikan.

Dengan demikian pengertian kurikulum dalam pandangan modern merupakan program pendidikan yang disediakan oleh sekolah, yang tidak hanya 
Volume 3 Nomor 1 Edisi Juni 2018

P-ISSN : 2541-3686

sebatas bidang studi dan kegiatan belajarnya saja, akan tetapi meliputi segala sesuatu yang dapat mempengaruhi perkembangan dan pembentukan pribadi peserta didik sesuai dengan tujuan pendidikan yang diharapkan sehingga dapat meningkatkan mutu kehidupannya, yang pelaksanaannya bukan saja di sekolah tetapi juga di luar sekolah.

Jika diaplikasikan dalam kurikulum pendidikan Islam, maka kurikulum berfungsi sebagai pedoman yang digunakan oleh pendidik untuk membimbing peserta didiknya kearah tujuan tertinggi pendidikan Islam, melalui akumulasi sejumlah pengetahuan, keterampilan dan sikap. Dalam hal ini proses pendidikan Islam bukanlah suatu proses yang dapat dilakukan secara sembarangan, tetapi hendaknya mengacu kepada konseptualisasi manusia sempurna (insan kamil) yang strateginya telah tersusun secara sistematis dalam kurikulum pendidikan Islam. (Ramayulis, 2008:152)

Dalam perkembangan selanjutnya, pengertian kurikulum tidak hanya terbatas pada program pendidikan namun juga dapat diartikan menurut fungsinya.

1. Kurikulum sebagai program studi.

Pengertiannya adalah seperangkat mata pelajaran yang mampu dipelajari oleh peserta didik di sekolah atau di instansi pendidikan lainnya.

2. Kurikulum sebagai konten.

Pengertiannya adalah data atau informasi yang tertera dalam buku-buku kelas tanpa dilengkapi dengan data atau informasi lainnya yang memungkinkan timbulnya belajar.

3. Kurikulum sebagai kegiatan berencana.

Pengertiannya adalah kegiatan yang direncanakan tentang hal-hal yang akan diajarkan dan dengan cara bagaimana hal itu dapat diajarkan dengan hasil yang baik.

4. Kurikulum sebagai hasil belajar.

Pengertiannya adalah seperangkat tujuan yang utuh untuk memperoleh suatu hasil tertentu tanpa menspesifikasikan cara-cara yang dituju untuk memperoleh hasil-hasil itu, atau seperangkat hasil belajar yang direncanakan dan diiinginkan.

5. Kurikulum sebagai reproduksi kultural.

Pengertiannya adalah transfer dan refleksi butir-butir kebudayaan masyarakat, agar dimiliki dan dipahami anak-anak generasi muda masyarakat tersebut.

6. Kurikulum sebagai pengalaman belajar.

Pengertiannya adalah keseluruhan pengalaman belajar yang direncanakan di bawah pimpinan sekolah.

7. Kurikulum sebagai produksi.

Pengertiannya adalah seperangkat tugas yang harus dilakukan untuk mencapai hasil yang ditetapkan terlebih dahulu. (Muhaimin dan Abdul Mujid, 1993:33) 


\section{Hakikat Kurikulum Pendidikan Islam \\ Muhammad Roihan Alhaddad}

\section{Komponen Kurikulum}

Kurikulum memiliki bagian-bagian penting dan penunjang yang dapat mendukung operasionalnya dengan baik yang disebut komponen yang saling berkaitan, berinteraksi dalam upaya mencapai tujuan. Ada 4 komponen utama kurikulum, yaitu : (Hasan langgulung, 1988:303)

1. Tujuan-tujuan yang ingin dicapai oleh pendidikan itu. Dengan lebih tegas lagi orang yang bagaimana yang ingin kita bentuk dengan kurikulum tersebut.

2. Pengetahuan (knowledge), informasi-informasi, data-data, aktifitas-aktifitas dan pengalaman-pengalaman dari mana terbentuk kurikulum itu. Bagian inilah yang disebut mata pelajaran.

3. Metode dan cara-cara mengajar yang dipakai oleh guru-guru untuk mengajar dan memotivasi peserta didik untuk membawa mereka ke arah yang dikehendaki oleh kurikulum.

4. Metode dan cara penilaian (evaluasi) yang dipergunakan dalam mengukur dan menilai kurikulum dan hasil proses pendidikan yang direncanakan kurikulum tersebut.

\section{Asas-asas Kurikulum Pendidikan Islam}

\section{a. Kerangka Dasar Kurikulum Pendidikan Islam}

Kurikulum yang baik dan relevan dalam rangka mencapai tujuan pendidikan Islam adalah yang bersifat intergrated dan komprehensif serta menjadikan Al-Quran dan Hadits sebagai sumber utama dalam penyusunannya. Di dalam Al-Qur'an dan Hadits ditemukan kerangka dasar yang dapat dijadikan sebagai pedoman operasional dalam penyusunan dan pengembangan kurikulum Pendidikan Islam. Kerangka dasar tersebut adalah:

\section{1) Tauhid}

Tauhid sebagai kerangka dasar kurikulum harus dimantapkan semenjak masih bayi, dimulai dengan memperdengarkan kalimat-kalimat tauhid seperti azan atau iqamah terhadap anak yang baru dilahirkan. (Ramayulis, 2008:155)

Dengan ketauhidan kita dapat mewujudkan tata dunia yang harmonis, kosmos (alam semesta) yang penuh tujuan, persamaan sosial, persamaan kepercayaan, persamaan jenis dan ras, persamaan dalam segala aktifitas dan kebebasan bahkan seluruh masyarakat dunia adalah sama yang disebut "ummatan wahidah". (Ramayulis, 2008:156)

Dengan demikian maka tauhid merupakan prinsip utama dalam seluruh dimensi kehidupan manusia baik dalam aspek hubungan vertikal antara manusia dengan Tuhan maupun aspek hubungan horizontal antara manusia sesamanya dan dengan alam sekitarnya, sehingga tercapai kehidupan yang sejahtera bahagia di dunia dan di akhirat, termasuk di dalamnya pergaulan dalam proses pendidikan. Tauhid yang seperti inilah yang dijadikan kerangka dasar kurikulum pendidikan Islam. 
RAUDHAH Proud To Be Professionals qurnal Tarbiyak7 damiyak

Volume 3 Nomor 1 Edisi Juni 2018

P-ISSN : 2541-3686

2) Perintah Membaca

Perintah "membaca" ayat-ayat Allah meliputi tiga macam ayat, yaitu:

a) Ayat Allah yang berdasarkan wahyu

b) Ayat Allah yang ada pada diri manusia

c) Ayat Allah yang terdapat di alam semesta di luar diri manusia

Ketiga macam ayat Allah tersebut jiwanya adalah "tauhid". Disinilah letaknya kurikulum pendidikan Islam, sebab menurut Islam, semua pengetahuan datang dari Allah, tetapi cara penyampaiannya ada yang langsung dari Allah dan ada pula yang melalui pemikiran manusia dan pengalaman indra yang berbeda satu sama lain.

Firman Allah:

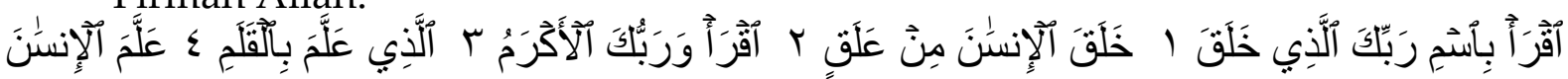

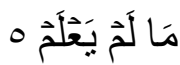

Artinya :

"Bacalah dengan (menyebut) nama Tuhanmu yang Menciptakan. Dia telah menciptakan manusia dari segumpal darah. Bacalah, dan Tuhanmulah yang Maha Pemurah, yang mengajar (manusia) dengan perantaran kalam. Dia mengajar kepada manusia apa yang tidak diketahuinya". (Q.S. Al-Alaq : 1-5)

Ditinjau dari segi kurikulum, sebenarnya Firman Allah SWT tersebut merupakan bahan pokok pendidikan yang mencakup seluruh ilmu pengetahuan yang dibutuhkan oleh manusia. Membaca selain melibatkan proses mental yang tinggi, pengenalan (cognition), ingatan (memory), pengamatan (perception), pengucapan (verbalization), pemikiran (reasoning), daya cipta (creativity). (Hasan Langgulung, 1985:166)

Motivasi yang terkandung dalam Q.S. Al-Alaq ayat 1-5 adalah agar manusia terdorong untuk mengadakan eksplorasi alam dan sekitarnya dengan kemampuan membaca dan menulisnya.

\section{b. Dasar Kurikulum Pendidikan Islam}

Dasar-dasar kurikulum merupakan kekuatan utama yang mempengaruhi dan membentuk materi kurikulum, susunan dan organisasi kurikulum.

Herman H. Home memberikan dasar bagi penyusunan kurikulum dengan tiga macam, yakni:

1) Dasar psikologis, yang digunakan untuk memenuhi dan mengetahui kemampuan yang diperoleh dari peserta didik dan kebutuhan peserta didik (the ability and needs of children).

2) Dasar sosiologis, yang digunakan untuk mengetahui tuntutan yang sah dari masyarakat (the legitimate demands of society).

3) Dasar filosofis, yang digunakan untuk mengetahui keadaan semesta/ tempat kita hidup (the kind of universe in which we live). (Muhaimin dan Abdul Mujid, 1993:85) 


\section{Hakikat Kurikulum Pendidikan Islam \\ Muhammad Roihan Alhaddad}

Sedangkan yang menjadi dasar dalam penyusunan kurikulum pendidikan Islam adalah :

1) Dasar Agama, dalam arti segala sistem yang ada dalam masyarakat termasuk pendidikan, harus meletakkan dasar falsafah, tujuan dan kurikulumnya pada dasar agama Islam (al-Qur'an, Hadits dan sumber-sumber yang bersifat furu' lainnya) dengan segala aspeknya.

2) Dasar Falsafah, yang memberikan pedoman bagi tujuan pendidikan Islam secara filosofis sehingga tujuan, isi dan organisasi kurikulum mengandung suatu kebenaran dan pandangan hidup dalam bentuk nilai-nilai yang diyakini sebagai suatu kebenaran, baik ditinjau dari segi ontologi, epistimologi maupun aksiologi.

3) Dasar Psikologi, memberikan landasan dalam perumusan kurikulum yang sejalan dengan ciri-ciri perkembangan psikis peserta didik, sesuai dengan tahap kematangan dan bakatnya, memperhatikan kecakapan pemikiran dan perbedaan perseorangan antara satu peserta didik dengan lainnya.

4) Dasar Sosial, memberikan gambaran bagi kurikulum pendidikan Islam yang tercermin pada dasar social yang mengandung ciri-ciri masyarakat Islam dan kebudayaannya. Sebab tidak ada suatu masyarakat yang tidak berbudaya dan tidak ada suatu kebudayaan yang tidak berada pada masyarakat. Kaitannya dengan kurikulum pendidikan Islam sudah tentu kurikulum ini harus mengakar terhadap masyarakat dan perubahan dan perkembangan.

5) Dasar Organisatoris, memberikan landasan dalam penyusunan bahan pembelajaran beserta penyajiannya dalam proses pembelajaran beserta penyajiannya dalam proses pembelajaran. (Iskandar dan Usman, 1988:49)

\section{Prinsip-prinsip kurikulum dalam Islam}

Prinsip-prinsip tersebut berbeda-beda menurut analisis para pakar kemudian ditambah dan disesuaikan dengan esensi kurikulum pendidikan Islam. (Iskandar dan Usman, 1988:520-522) Prinsip-prinsip tersebut adalah sebagai berikut :

a. Prinsip berasaskan Islam termasuk ajaran dan nilai-nilainya. Maka setiap yang berkaitan dengan kurikulum, termasuk falsafah, tujuan-tujuan, kandungankandungan, metode mengajar, cara-cara perlakuan dan hubungan-hubungan yang berlaku dalam lembaga-lembaga pendidikan harus berdasarkan pada agama dan akhlak Islam.

b. Prinsip mengarah kepada tujuan adalah seluruh aktifitas dalam kurikulum diarahkan untuk mencapai tujuan yang dirumuskan sebelumnya.

c. Prinsip (integritas) antara mata pelajaran, pengalaman-pengalaman dan aktifitas yang terkandung di dalam kurikulum, begitu pula dengan pertautan antara kandungan kurikulum dengan kebutuhan peserta didik juga kebutuhan masyarakat. 
P-ISSN : 2541-3686

d. Prinsip relevansi adalah adanya kesesuaian pendidikan dengan lingkungan hidup peserta didik, relevansi dengan kehidupan masa sekarang dan akan datang, relevansi dengan tuntutan pekerjaan.

e. Prinsip fleksibilitas adalah terdapat ruang gerak yang memberikan sedikit kebebasan dalam bertindak, baik yang berorientasi pada fleksibilitas pemilihan program pendidikan maupun dalam mengembangkan program pengajaran.

f. Prinsip integritas adalah kurikulum tersebut dapat menghasilkan manusia seutuhnya, manusia yang mampu mengintegrasikan antara fakultas dzikir dan fakultas pikir, serta manusia yang dapat menyelaraskan struktur kehidupan dunia dan struktur kehidupan akhirat.

g. Prinsip efisiensi adalah agar kurikulum dapat mendayagunakan waktu, tenaga, dana, dan sumber lain secara cermat, tepat, memadai dan dapat memenuhi harapan.

h. Prinsip kontinuitas dan kemitraan adalah bagaimana susunan kurikulum yang terdiri dari bagian yang berkelanjutan dengan kaitan-kaitan kurikulum lainnya, baik secara vertikal (penjenjangan, tahapan) maupun secara horizontal.

i. Prinsip individualitas adalah bagaimana kurikulum memperhatikan perbedaan pembawaan dan lingkungan anak pada umumnya yang meliputi seluruh aspek pribadi peserta didik, seperti perbedaan jasmani, watak, intelegensi, bakat serta kelebihan dan kekurangannya.

j. $\quad$ Prinsip kesamaan memperoleh kesempatan, dan demokratis adalah bagaimana kurikulum dapat memberdayakan semua peserta didik dalam memperoleh pengetahuan, keterampilan dan sikap sangat diutamakan. Seluruh peserta didik dari berbagai kelompok seperti kelompok yang kurang beruntung secara ekonomi dan sosial yang memerlukan bantuan khusus, berbakat dan unggul berhak menerima pendidikan yang tepat sesuai dengan kemampuan dan kecepatannya.

k. Prinsip kedinamisan adalah agar kurikulum itu tidak statis, tetapi dapat mengikuti perkembangan ilmu pengetahuan dan perubahan sosial.

1. Prinsip keseimbangan adalah bagaimana kurikulum dapat mengembangkan sikap potensi peserta didik secara harmonis.

m. Prinsip efektifitas adalah agar kurikulum dapat menunjang efektiftas pendidik yang mengajar dan peserta didik yang belajar.

\section{Orientasi kurikulum dalam Islam}

Kurikulum pendidikan Islam berorientasi kepada : (Ramayulis, 2008:166-168)

a. Orientasi pelestarian nilai.

Dalam pandangan Islam, nilai terbagi atas dua macam, yaitu nilai yang turun dari Allah SWT (nilai Ilahiyah) dan nilai yang tumbuh dan berkembang dari peradaban manusia sendiri (nilai Insaniah). Kedua nilai tersebut selanjutnya 


\section{Hakikat Kurikulum Pendidikan Islam Muhammad Roihan Alhaddad}

membentuk norma-norma atau kaidah-kaidah kehidupan yang dianut dan melembaga pada masyarakat yang mendukungnya.

Tugas kurikulum selanjutnya adalah menciptakan situasi-situasi dan program tertentu untuk tercapainya pelestarian kedua nilai tersebut. Orientasi ini memfokuskan kurikulum sebagai alat untuk tercapainya "agent of conservative".

b. Orientasi pada peserta didik

Orientasi ini memberikan pedoman arah pada kurikulum untuk memenuhi kebutuhan peserta didik yang disesuaikan dengan bakat, minat dan potensi yang dimilikinya, serta kebutuhan peserta didik. Orientasi ini diarahkan kepada pembinaan tiga dimensi peserta didiknya, yakni:

1) Dimensi kepribadian sebagai manusia, yaitu kemampuan untuk menjaga integritas antara sikap, tingkah laku etiket dan moralitas.

2) Dimensi produktivitas yang menyangkut apa yang dihasilkan peserta didik dalam jumlah yang lebih banyak kualitas yang lebih baik setelah ia menamatkan pendidikannya.

3) Dimensi kreatifitas yang menyangkut kemampuan peserta didik untuk berfikir dan berbuat, menciptakan sesuatu yang berguna bagi diri sendiri dan masyarakat.

c. Orientasi pada masa depan perkembangan ilmu pengetahuan dan teknologi (IPTEK).

Kemajuan suatu zaman ditandai oleh kemajuan ilmu pengetahuan dan teknologi serta produk-produk yang dihasilkannya. Hampir semua segi kehidupan dewasa ini tidak lepas dari keterlibatan IPTEK mulai dari kehidupan yang paling sederhana sampai kehidupan dan peradaban yang paling tinggi.

d. Orientasi pada social demand (tuntutan sosial)

Kehidupan adalah berkembang, tanpa perkembangan berarti tidak ada kehidupan. Masyarakat yang maju adalah masyarakat yang ditandai oleh munculnya berbagai peradaban dan kebudayaan sehingga masyarakat tersebut mengalami perubahan dan perkembangan yang pesat.

Orientasi kurikulum adalah bagaimana memberikan kontribusi positif dalam perkembangan sosial dan kebutuhannya, sehingga out put di lembaga pendidikan mampu menjawab dan mengatasi masalah-masalah yang dihadapi masyarakat.

e. Orientasi penciptaan tenaga kerja

Kebutuhan-kebutuhan manusia yang sifatnya lahiriah seperti: makan,minum, dan bertempat tinggal yang layak harus dipenuhi secara layak dan salah satu diantara persiapan untuk mendapatkan pemenuhan kebutuhan yang layak adalah melalui pendidikan. Dengan pendidikan, pengalaman dan pengetahuan seseorang bertambah dan dapat menentukan kualitas dan kuantitas kerja seseorang, sehingga dewasa ini dunia kerja semakin banyak persaingan.

Sebagai konsekuensinya, kurikulum pendidikan diarahkan untuk memenuhi kebutuhan kerja, yang ditujukan setelah lulus dari lembaga sekolah, peserta didik mempunyai kemampuan dan keterampilan yang profesional, berproduktif dan 
Volume 3 Nomor 1 Edisi Juni 2018

P-ISSN : 2541-3686

kreatif, mampu mendayagunakan sumber daya alam, sumber daya diri dan sumber daya situasi yang mempengaruhinya.

f. Orientasi penciptaan lapangan kerja

Orientasi ini tidak hanya memberikan arahan kepada kurikulum bagaimana menciptakan peserta didik yang terampil agar dapat mengisi lapangan kerja di dalam masyarakat, dikarenakan terbatasnya lapangan kerja. Maka kurikulum hendaknya dapat pula menciptakan peserta didik yang dapat membuat lapangan kerja baru yang dapat menyerap tenaga kerja terutama dirinya dan orang lain. Sehingga orientasi hidupnya tidak bergantung kepada orang lain.

\section{Simpulan}

Pengertian kurikulum dalam pandangan modern merupakan program pendidikan yang disediakan oleh sekolah, yang tidak hanya sebatas bidang studi dan kegiatan belajarnya saja, akan tetapi meliputi segala sesuatu yang dapat mempengaruhi perkembangan dan pembentukan pribadi peserta didik sesuai dengan tujuan pendidikan yang diharapkan sehingga dapat meningkatkan mutu kehidupannya, yang pelaksanaannya bukan saja di sekolah tetapi juga di luar sekolah.

Ada 4 komponen utama kurikulum, yaitu tujuan-tujuan yang ingin dicapai, pengetahuan (knowledge), metode dan cara-cara mengajar serta metode dan cara penilaian (evaluasi).

Prinsip-prinsip kurikulum dalam Islam antara lain : prinsip berasaskan Islam, prinsip mengarah kepada tujuan, prinsip (integritas) antar mata pelajaran, prinsip relevansi, prinsip fleksibilitas, prinsip integritas, prinsip efisiensi, prinsip kontinuitas, prinsip individualitas, prinsip kesamaan, prinsip kedinamisan, prinsip keseimbangan dan prinsip efektifitas. Kurikulum pendidikan Islam berorientasi kepada pelestarian nilai, peserta didik, masa depan perkembangan ilmu pengetahuan dan teknologi (IPTEK), social demand (tuntutan sosial), penciptaan tenaga kerja dan orientasi penciptaan lapangan kerja. 


\section{DAFTAR PUSTAKA}

Nata, Abuddin. 1997. Filsafat Pendidikan Islam I, Jakarta: Logos Wacana Ilmu.

Fahmi, Asma Hasan. 1987. Sejarah dan Filsafat Pedidikan Islam, Jakarta: Bulan Bintang. Langgulung, Hasan. 1988. Asas-asas Pendidikan Islam, Jakarta: Pustaka Al-Husna.

, 1986. Manusia dan Pendidikan Suatu Analisa Psikologi Pendidikan, Jakarta: Pustaka Al-Husna.

, 1985. Pendidikan dan Peradaban Islam, Jakarta: Pustaka Al-Husna.

Wiryokusumo, Iskandar dan Mulyadi, Usman. 1988. Dasar-dasar Pengembangan Kurikulum, Jakarta: Bina Aksara.

Muhaimin dan Mujib, Abdul. 1993. Pemikiran Pendidikan Islam Kajian Filosofis dan Kerangka Dasar Operasionalnya, Bandung: Trigenda Karya.

Ramayulis, 2008. Ilmu Pendidikan Islam, Jakarta: Penerbit Kalam Mulia.

Nizar, Samsul. 2002. Filsafat Pendidikan Islam, Pendekatan Historis, Teoritis dan Praktis, Jakarta: Quantum Teaching. 